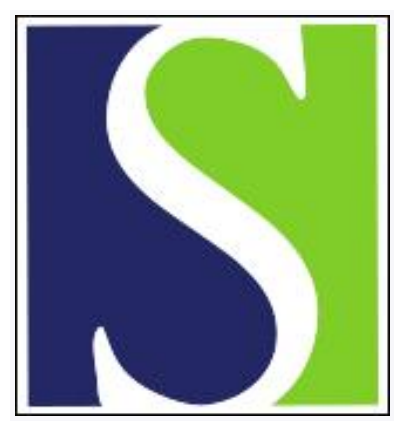

Scand J Work Environ Health 1996;22(3):182-190

https://doi.org/10.5271/sjweh.129

Issue date: Jun 1996

Terpene exposure and respiratory effects among sawmill workers

by Eriksson KA, Stjernberg NL, Levin JO, Hammarström U, Ledin MC

The following article refers to this text: $2001 ; 27(1): 76-81$

Key terms: bronchial reactivity; diffusion capacity; metabolite; sawing fume

This article in PubMed: www.ncbi.nlm.nih.gov/pubmed/8837263

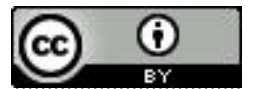




\title{
Terpene exposure and respiratory effects among sawmill workers
}

\author{
by Kåre A Eriksson, BSC, ${ }^{1,2,3}$ Nils L Stjernberg, MD, ${ }^{2}$ Jan O Levin, PhD, ${ }^{2}$ Ulf Hammarström, ${ }^{2}$ Maj C Ledin ${ }^{2}$
}

\begin{abstract}
Eriksson KA, Stjernberg NL, Levin J0, Hammarström U, Ledin MC. Terpene exposure and respiratory effects among sawmill workers. Scand J Work Environ Health 1996;22:182-90.

Objectives This study was performed to evaluate exposure to terpenes in sawmills and to study the acute effects on lung function and the respiratory tract of exposed laborers.

Methods The relationships between personal exposure to sawing fumes, assessed by air sampling, and terpene metabolites in urine were studied. The association between exposure to terpenes and acute effects on lung function was studied for 48 workers. The reactivity to methacholine within the study population was investigated. Variation in acute subjective respiratory symptoms during a workshift was evaluated by interviewing the employees before and after work, following a standardized questionnaire.

Results Personal exposure to terpenes in the sawmills was $11-158 \mathrm{mg} \cdot \mathrm{m}^{-3}$. The correlation (correlation coefficient $=0.84$ ) between exposure to $\alpha$-pinene and the concentration of verbenols (metabolites from $\alpha$-pinene) in urine was good. No acute effects on forced vital capacity or forced expiratory volume during $1 \mathrm{~s}$ were detected. A decrease in carbon monoxide lung diffusing capacity after a workshift was detected. Workers with $\geq 5$ years of sawmill employment showed a higher reactivity to methacholine than those with $<5$ years. Eye irritation increased during a workday.

Conclusions Personal exposure to monoterpenes during a workshift sometimes exceeds the present Swedish limit value. The results show that verbenols in urine can be used as a biological exposure index of sawing fumes. Exposure in sawmills can cause an acute decrease in diffusing capacity. Workers with $\leq 5$ years of employment showed increased bronchial reactivity.
\end{abstract}

Key terms bronchial reactivity, diffusing capacity, metabolites, sawing fumes.

The Swedish saw industry employs approximately 20000 workers (1), which makes it one of the main branches of industry in Sweden. Most of the employees are involved in the production of lumber from spruce (Picea abies) and pine (Pinus sylvestris), which are the dominant tree species used in Swedish sawmills.

A sawmill is an industrial plant usually consisting of a saw shed, a kiln, and a grading house. In the saw shed, the barked trees are sawn into center boards and edge boards. Unsightly edges are sawn away, and the finished board and planks are sorted according to size before being transported to the kiln. In the kiln, the boards are kept at a temperature of approximately $25-45^{\circ} \mathrm{C}$ for $24-48 \mathrm{~h}$ to reduce the water content of the planks to $15-20 \%$ (weight/weight). After the drying procedure is completed, the boards are transported to the grading house, where they are quality rated by specially trained personnel. Finally, the wooden products are sold to cus- tomers such as joinery shops, cabinet makers, and construction industries in Sweden, as well as in the rest of Europe.

During sawing, and especially during the sawing of pine, the monoterpenes $\alpha$-pinene, $\beta$-pinene and $\triangle^{3}$-carene, the main volatile compounds present in sawing fumes, are released into the work environment. The personal exposure to these substances in saw sheds often exceeds the present Swedish threshold limit value of $150 \mathrm{mg} \cdot \mathrm{m}^{-3}(2,3)$. Nobody works in the kiln, as the drying procedure is completely automated, and the main task for the operator is to supervise the process via data terminals situated in a separate room.

In the grading house, the personal exposure to sawing fumes is relatively low during a workday, usually $5-15 \mathrm{mg} \cdot \mathrm{m}^{-3}$ (unpublished observations), since the wood has been dried.

Personal exposure to monoterpenes in sawmills can be assessed from pumped sampling using charcoal ad-

1 Department of Occupational and Environmental Medicine, University Hospital of Northern Sweden, Umeå, Sweden.

2 National Institute of Working Life, Umeå, Sweden.

3 Royal Institute of Technology, Department of Work Science, Stockholm, Sweden.

Reprint requests to: Mr Kåre A Eriksson, Department of Occupational and Environmental Medicine, University Hospital of Northern Sweden, S-901 85 Umeå, Sweden. 
sorbent tubes, as well as by diffusive sampling of the workplace air $(4,5)$.

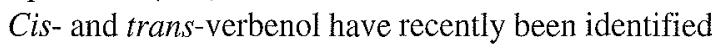
as metabolites from $\alpha$-pinene in human urine after occupational exposure to sawing fumes (2). The elimination kinetics of $\alpha$-pinene in humans has also been studied. Subjects were exposed to 450,225 , and $10 \mathrm{mg} \cdot \mathrm{m}^{-3}$ in an exposure chamber for $2 \mathrm{~h}$, and verbenols in urine samples, collected at different time intervals $(0,2,4$ and $21 \mathrm{~h}$ ) after the end of exposure, were quantified (6). Verbenols can be identified in human urine within $2 \mathrm{~h}$ after the end of the exposure at all three levels. Thus quantification of verbenols in urine samples collected immediately after the end of a workshift can be used as a technique to evaluate the possibility of a worker being exposed to sawing fumes during a workday.

Exposure to wood dust from California redwood, oak, mahogany (hard woods), cedar, pine, or spruce (soft woods) has been known to cause increased respiratory symptoms (7) and occupational asthma (8). Nonasthmatic chronic airflow obstruction has been shown after exposure to sawing fumes and wood dust from pine (3), and simple chronic bronchitis has occurred among cedar and noncedar sawmill workers (9). Studies in Swedish sawmills have earlier shown a decrease in the forced expiratory volume during $1 \mathrm{~s}\left(\mathrm{FEV}_{1.0}\right)$ and the percentage of increased closing volume (CV\%) for sawmill workers (3). After the reduction of sawing fumes in a Swedish sawmill, an eight-year follow-up study showed relative improvement in lung function among the employees working in the saw shed (10).

The monoterpenes $\alpha$-pinene, $\beta$-pinene, and $\Delta^{3}$-carene are also known to be irritating to skin and mucous membranes in humans and can cause both allergic and nonallergic contact dermatitis (11-13).

The aim of the present study was to evaluate sawmill employees' exposure to sawing fumes during a workshift by air sampling and the determination of cis- and trans-verbenol in urine samples. We also wanted to determine whether exposure to sawing fumes from pine caused any acute effects on the laborers' lung function or induced acute subjective respiratory symptoms during a workshift. As wood dust (3, 7-9) and microorganisms (14) are suspected irritants to the respiratory tract among humans, and are thus able to cause the acute effects studied by us, exposure to these substances in the sawmills was also evaluated.

\section{Subjects and methods}

\section{Study population}

The workers who took part in our study (47 men, 1 woman) participated voluntarily. At each sawmill, the investigation was performed during four consecutive work shifts, and there were up to three workers during each shift. Each worker examined was busy in the saw shed during the whole, or a major part, of the workshift the day of the investigation. The sawmills were all processing pine when the study was performed, and the employees were doing their usual tasks, such as sawing, edging and sorting the logs, as well as sweeping saw dust away from the floor, the machinery, and the conveyors. The production of lumber in each sawmill was normal during the time of the study.

Of the work force studied, 20 workers (42\%) were smokers, 20 were nonsmokers, and $8(16 \%)$ were exsmokers. The mean age was 37 (SD 9.8) years, the mean height was 179 (SD 8.1) cm, and the mean weight was 78 (SD 12.3) kg. Their mean duration of exposure in sawmills was 11.8 (SD 9.7) years.

The subjects had worked within the saw shed during most of the time employed at a sawmill, but not necessarily at the sawmill under investigation. We grouped them according to employment time $[\leq 5$ years $(N=15)$, $5-15$ years $(\mathrm{N}=18)$, and $\geq 15$ years $(\mathrm{N}=15)]$ when interpreting the medical examinations.

\section{Exposure assessments of monoterpenes}

Air sampling of the personal exposure to monoterpenes in the sawmills was performed by diffusive sampling (SKC model 530-16, Eighty four, Pennsylvania, United States) with charcoal as the adsorbent (SKC 53004). The sampler was attached to the lapel of the worker's overalls, and the sampling period was $6-8 \mathrm{~h}$. The uptake rate for the monoterpenes $\alpha$-pinene, $\beta$-pinene, and $\triangle^{3}$-carene by the sampler used was $8.6,8.6$, and $8.3 \mathrm{ml} \cdot \mathrm{min}^{-1}$, respectively (5). The samplers were kept at $-20^{\circ} \mathrm{C}$ until the analysis (within one week). The analysis of the monoterpenes was performed by gas chromatography using a capillary column with a nonpolar phase. The analytical parameters have been described in detail elsewhere (2).

\section{Biological monitoring}

Urine samples from all the workers who took part in the study were collected before and within $10 \mathrm{~min}$ after the end of the workshift and were kept frozen $\left(-20^{\circ} \mathrm{C}\right)$ until the analysis (within one month) of the verbenols. The urine samples were hydrolyzed with $\beta$-glucuronidase at $37^{\circ} \mathrm{C}$ for $24 \mathrm{~h}$, cleaned by solid phase extraction, and analyzed by gas chromatography using a capillary column with a semipolar phase. The analytical method has been described in detail earlier (2).

Verbenols were quantified in urine samples collected before the workshift from almost every worker. The detection of these substances in the morning urine indicated that $\alpha$-pinene or $c i s$ - and trans-verbenol were retained in the human body following exposure to sawing fumes 1 to $4 \mathrm{~d}$ before the day of investigation. According 
to Falk et al (15), experimental exposure of humans to $\alpha$-pinene in an exposure chamber for $2 \mathrm{~h}$ showed that this monoterpene had a long half-time in poorly perfused tissues, indicating a high affinity to adipose tissue. The authors concluded that it would take more than $2 \mathrm{~d}$ for the body to be almost completely cleared of $\alpha$-pinene after a single exposure. Thus exposure to sawing fumes during consecutive workshifts may give rise to a body burden of $\alpha$-pinene in humans by accumulation of the monoterpene in tissues rich in fat.

Our excretion data from the kinetic study showed the existence of two rate constants for the elimination of $\alpha$-pinene as verbenols from the human body. The elimination half-times $\left(t_{1 / 2}\right)$ were 0.6 and $6 \mathrm{~h}(6)$. Thus the elimination half-time of $6 \mathrm{~h}$ indicated that some of the inhaled $\alpha$-pinene was retained in the human body after exposure.

When the concentration of verbenols in the postshift urine samples from exposed persons was calculated, there was probably a contribution of verbenols due to the excretion of accumulated $\alpha$-pinene, as the workers had been exposed to sawing fumes 1 to $4 \mathrm{~d}$ before the study was conducted. We have not corrected for this contribution when determining the metabolite concentrations.

\section{Total dust}

The personal exposure to wood dust was carried out by the $37-\mathrm{mm}$ open cassette method with an airflow of $21 \cdot \mathrm{min}^{-1}$ through the filter. The workers wore the sampling pump (SKC 224-PCXR7), to which the filter cassette was connected via a plastic tube, during the whole workshift of $6-8 \mathrm{~h}$. The filters were conditioned for $16 \mathrm{~h}$ at $21^{\circ} \mathrm{C} \pm 0.5^{\circ} \mathrm{C}$ and at a relative humidity of $55 \% \pm 2 \%$. The filters were weighed before and after the sampling period.

\section{Microorganisms}

The exposure to microorganisms in the different sawmills was assessed with the use of static area sampling. The sampling equipment was placed in the saw shed as close to the work area as possible. One sample was collected during each workshift, and the sampling rate through the filter (Nuclepore, $37 \mathrm{~mm}, \mathrm{SN} 311344,3 \mathrm{PC}$ ) was $1.0-2.01 \cdot \mathrm{min}^{-1}$. The sampling time was approximately $8 \mathrm{~h}$. The filters were kept in a refrigerator $\left(+5^{\circ} \mathrm{C}\right)$ until the analysis. The total number of airborne microorganisms (living and dead) in the samples was determined by acridine orange staining and epifluoresence microscopy (16).

\section{Interviews}

All the workers were interviewed according to a standardized questionnaire, with questions covering work tasks, earlier employment, health status, smoking habits, and symptoms from the respiratory tract. The workers were interviewed by a technician specialized in the field of lung physiology, before and immediately after a workshift, and subjective symptoms according to a questionnaire were registered. The symptoms were headache, dizziness, nausea, tiredness, tightness of the chest, coughing, difficult breathing, eye irritation, nasal irritation, unpleasant smell, throat irritation, skin irritation, and a bad taste in the mouth. The symptoms were scored according to the Borg scale (17), and the scoring was performed for 43 individuals. One individual became ill and one had an accident; therefore, they could not attend the scoring test. Two workers left after work without answering the questions, and one person misunderstood the instructions given, the result being an inapplicable scoring test.

\section{Lung function tests}

Dynamic spirometry and carbon monoxide lung diffusing capacity $\left(\mathrm{DL}_{\mathrm{CO}}\right)$ were measured using the Sensor Medic Pulmolab 2100 (Sensor Medics, Anaheim, California, United States). The dynamic spirometry test included forced vital capacity (FVC), $\mathrm{FEV}_{1.0}$, and a flow volume loop, measuring maximal forced expiratory flows during $25-75 \%$ of the FVC $\left(\mathrm{FEF}_{25-75}\right)$, and at $50 \%\left(\mathrm{FEF}_{50}\right)$ and $75 \%\left(\mathrm{FEF}_{75}\right)$ of the FVC. Three examinations were performed, with a maximal tolerated difference of $5 \%$ between the highest and next highest value of the FVC and $\mathrm{FEV}_{1.0}$. The best examination was chosen for the analysis according to the criteria of the American Thoracic Society (18). All the air volumes are given at body temperature, pressure saturated (BTPS). To calculate the lung function values as the percentage of the predicted values, local reference values were used (unpublished observations). The $\mathrm{DL}_{\mathrm{CO}}$ was measured using a modified single breath carbon monoxide method (19). $\mathrm{DL}_{\mathrm{CO}}$ is expressed as the amount of carbon monoxide (CO) uptake per unit of alveolar-capillary pressure difference for $\mathrm{CO}$ $\left(\mathrm{mmol} \cdot \mathrm{kPa}^{-1} \cdot \mathrm{min}^{-1}\right.$ ). Reference values of the European Community were used for coal and steel (20).

All the lung function tests and the $\mathrm{DL}_{\mathrm{Co}}$ measurements were made with the subject seated in an upright posture, and a nose clip was used during the investigation. The smokers were told not to smoke for $4 \mathrm{~h}$ before the tests. The lung function tests were carried out before and immediately after a workshift, dynamic spirometry being measured for 46 workers and diffusing capacity for 38 workers. Two persons became ill during the day and left without performing the dynamic spirometry and $\mathrm{DL}_{\mathrm{CO}}$. Technical problems caused an additional eight missing results from the $\mathrm{DL}_{\mathrm{CO}}$ test.

\section{Methacholine test}

The methacholine test was performed according to Malmberg et al (21). It was carried out one day after the other lung function tests. The subjects were told not to 
smoke or drink coffee for $4 \mathrm{~h}$ before the test. The methacholine test started with three FVC maneuvers using a Vitalograph ${ }^{\circledast}$ spirometer (Vitalograph Ltd, Buckingham, England). At least $5 \mathrm{~min}$ after the FVC test, the first inhalation (diluent) was given during $1 \mathrm{~min}$. Five minutes after the inhalation of the methacholine, the $\mathrm{FEV}_{1.0}$ was measured. Thereafter, with an interval between each dose-step of $6 \mathrm{~min}$, methacholine was inhaled in doses of $0.5,2,8$, and $32 \mathrm{mg} \cdot \mathrm{ml}^{-1}$. The cumulated dose causing a $20 \%$ decrease in $\mathrm{FEV}_{1.0}\left(\mathrm{PD}_{20}\right)$ and the slope (percentage of change in $\mathrm{FEV}_{1} \cdot \mathrm{mg}^{-1}$ cumulated inhaled dose of methacholine) was calculated.

Thirty-three persons performed the methacholine tests. The test was not conducted at one of the sawmills $(\mathrm{N}=12)$. One person had a cold and could not do the test, one worker had left his job at the sawmill by the time the test was to be executed, and one person did not appear for the test.

\section{Statistical analysis}

Data were analyzed using the following statistical tests: Wilcoxon signed rank (Rank-Sum) test, the chi-square test (Fishers exact test), Mann-Whitney rank sum test, and the Spearman correlation test.

\section{Results}

\section{Air sampling of monoterpenes}

The geometric means (GM) of the personal exposure to monoterpenes in the four different sawmills varied from 36 to $85 \mathrm{mg} \cdot \mathrm{m}^{-3}$ (table 1 ). To evaluate the results of the medical examinations, we grouped the workers from all the sawmills into two exposure classes: those with a daily average exposure of $\leq 50 \mathrm{mg} \cdot \mathrm{m}^{-3}$ of total terpenes $(\mathrm{N}=18)$ and those with a daily average exposure of $>50 \mathrm{mg} \cdot \mathrm{m}^{-3}(\mathrm{~N}=30)$ during the day of the investigation. Exposure to $\leq 50 \mathrm{mg}^{-3}$ (ie, one-third of the present limit value of $150 \mathrm{mg} \cdot \mathrm{m}^{-3}$ ) was suggested to be a relatively low exposure to sawing fumes, while exposure to $>50 \mathrm{mg} \cdot \mathrm{m}^{-3}$ was suggested to be medium to high exposure.

\section{Biological monitoring}

We studied whether determining verbenols in urine samples collected after the end of a workshift could be used as a biological exposure index for terpenes. The correlation between the concentration of verbenols in the employees' urine at the end of a workshift, expressed as micromoles of verbenol per millimole of creatinine, and the average personal exposure to $\alpha$-pinene, in milligrams per cubic meter, is illustrated for each worker in figure 1.

Table 1 shows the geometric and arithmetic means of the verbenols in postshift urine samples from the exposed workers at the different sawmills. The workers who had the highest daily average mean exposure to sawing fumes at the third and fourth sawmill also had the highest concentration of verbenols in their urine at the end of the workshift.

\section{Wood dust and microorganisms}

The personal exposure to wood dust at the sawmills was $0.1-1.1 \mathrm{mg} \cdot \mathrm{m}^{-3}$, as shown in table 1 .

The results from the static area sampling (12 samples) of the microorganisms showed levels of $1.5 \times 10^{4}-$ $1.3 \times 10^{5}$ of the total number of airborne microorganisms (living and dead) in the sawmills studied.

\section{Symptom scoring}

Table 2 shows the change in symptom scoring from before to immediately after a workshift. The scoring of eye irritation increased significantly over the workshift ( $\mathrm{P}<0.05$, Wilcoxon signed rank test). Symptom scoring between the two terpene exposure groups was not statistically significant for any of the symptoms $(\mathrm{P}>0.05$, Mann-Whitney rank sum test).

No statistically significant difference was seen in the number of persons with increasing acute symptoms in the low and medium-high exposure groups $(\mathrm{P}>0.05$, chi square).

\section{Lung function tests}

The mean values for all the measured variables were between $91.9 \%$ and $100.9 \%$ of the predicted value for the whole group of sawmill workers (table 3). Four per-

Table 1. Geometric means (GM) and arithmetic means (AM) of monoterpene exposure (mg $\cdot \mathrm{m}^{-3}$ ) at the sawmills which took part in the study. The exposure to wood dust $\left(\mathrm{mg} \cdot \mathrm{m}^{-3}\right)$ and concentration of verbenols $\left(\mu \mathrm{mol} \cdot \mathrm{mmol}\right.$ creatinine $\left.\mathrm{e}^{-1}\right)$ are also expressed in geometric and arithmetic means.

\begin{tabular}{|c|c|c|c|c|c|c|c|c|c|c|c|c|c|}
\hline \multirow[t]{2}{*}{ Sawmill } & \multirow{2}{*}{$\begin{array}{l}\text { Workers } \\
\text { examined } \\
(\mathrm{N})\end{array}$} & \multicolumn{3}{|c|}{ Total terpenes } & \multicolumn{3}{|c|}{ Wood dust } & \multicolumn{3}{|c|}{$\begin{array}{l}\text { Verbenols in } \\
\text { preshift urine }\end{array}$} & \multicolumn{3}{|c|}{$\begin{array}{l}\text { Verbenols in } \\
\text { postshift urine }\end{array}$} \\
\hline & & GM & $A M$ & Range & GM & AM & Range & GM & AM & Range & GM & $\mathrm{AM}$ & Range \\
\hline $\begin{array}{l}1 \\
2 \\
3 \\
4\end{array}$ & $\begin{array}{r}9 \\
15 \\
12 \\
12\end{array}$ & $\begin{array}{l}36 \\
51 \\
81 \\
81\end{array}$ & $\begin{array}{l}47 \\
61 \\
91 \\
88\end{array}$ & $\begin{array}{l}11-135 \\
13-158 \\
35-151 \\
34-145\end{array}$ & $\begin{array}{l}0.4 \\
0.3 \\
0.2 \\
0.3\end{array}$ & $\begin{array}{l}0.5 \\
0.4 \\
0.2 \\
0.4\end{array}$ & $\begin{array}{l}0.2-1.1 \\
0.1-0.7 \\
0.1-0.5 \\
0.2-0.6\end{array}$ & $\begin{array}{l}1.58 \\
0.43 \\
1.31 \\
1.46\end{array}$ & $\begin{array}{l}1.05 \\
0.43 \\
1.27 \\
1.69\end{array}$ & $\begin{array}{l}0.70-4.16 \\
0.07-0.81 \\
0.70-2.16 \\
0.42-5.30\end{array}$ & $\begin{array}{l}4.21 \\
6.88 \\
9.30 \\
9.58\end{array}$ & $\begin{array}{c}5.63 \\
9.34 \\
13.2 \\
11.4\end{array}$ & $\begin{array}{l}1.31-9.65 \\
1.45-25.1 \\
2.94-32.8 \\
4.33-18.5\end{array}$ \\
\hline All & 48 & 60 & 73 & $11-158$ & 0.3 & 0.3 & $0.1-1.1$ & 1.00 & 1.07 & $0.07-5.30$ & 7.72 & 10.1 & $1.31-32.8$ \\
\hline
\end{tabular}




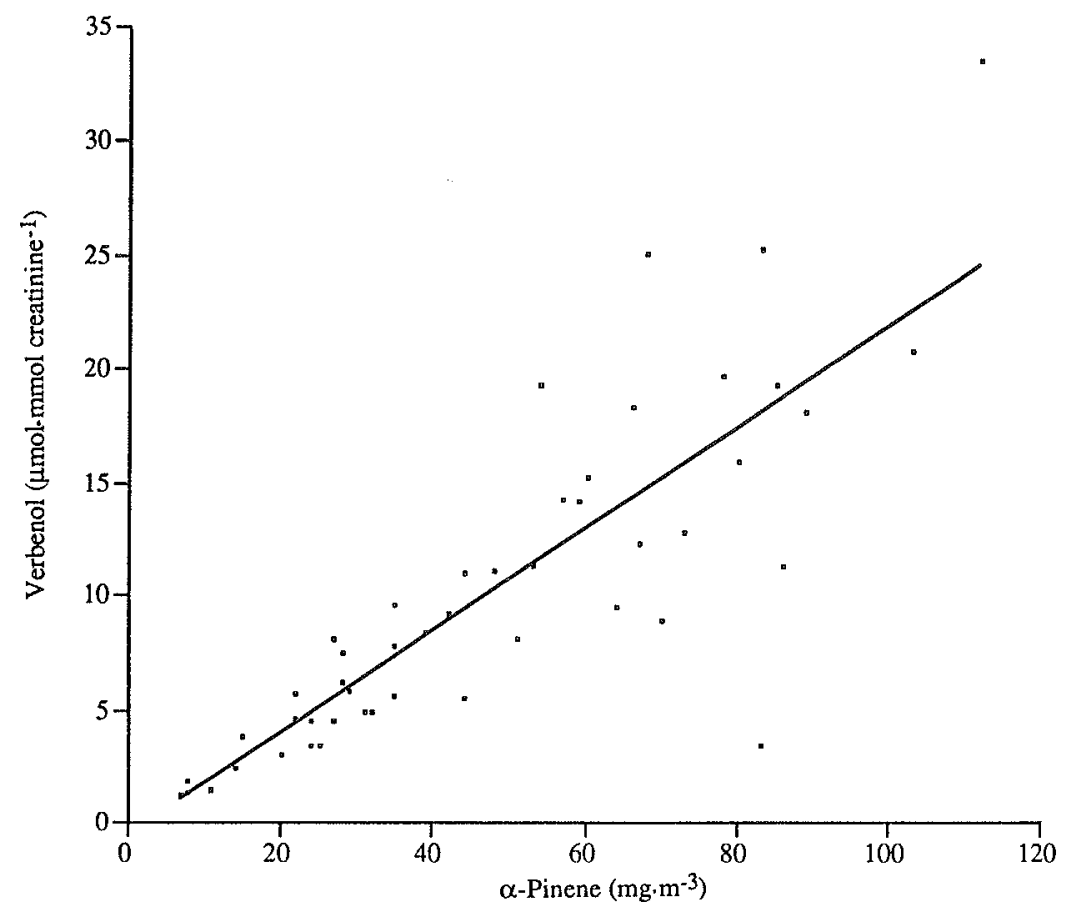

Figure 1. Correlation between personal exposure $(N=48)$ to $\alpha$-pinene as the air concentration during a workshift and the urinary concentration of verbenols at the end of that same workshift. Regression line: $y=-0.41+0.22 x$. Coefficient of correlation $=0.84$.
Table 2. Number of persons with increased or decreased subjective symptoms after the end of a workshift at the sawmills. The Wilcoxon sign rank test was used for significance testing. (NS = not significant)

\begin{tabular}{lccc}
\hline Symptom & $\begin{array}{c}\text { Increased } \\
\text { symptoms }\end{array}$ & $\begin{array}{c}\text { Decreased } \\
\text { symptoms }\end{array}$ & Significance \\
\hline Headache & 5 & 3 & NS \\
Tiredness & 15 & 8 & NS \\
Chest tightness & 3 & 2 & NS \\
Cough & 4 & 12 & NS \\
Eye irritation & 10 & 2 & $<0.01$ \\
Nose irritation & 6 & 10 & NS \\
Throat irritation & 8 & 7 & NS \\
Skin irritation & 3 & 2 & NS \\
\hline
\end{tabular}

sons had an FVC of less than $80 \%$ of the predicted value, and six workers had an $\mathrm{FEV}_{1.0}$ of less than $80 \%$ of the predicted value.

There was a tendency, but the difference was not statistically significant, towards a decrease in $\mathrm{DL}_{\mathrm{CO}}$ in the two groups with shorter employment time when they were compared with the group with more than 15 years of employment $(\mathrm{P}>0.05$, Mann-Whitney rank sum test). There were no significant changes in the lung function data over the workshift, except for the $\mathrm{DL}_{\mathrm{CO}}(\mathrm{P}<0.05$, Wilcoxon signed rank test), which is shown in figure 2. Figure 3 (FVC and $\left.\mathrm{FEV}_{1.0}\right)$ and figure $4\left(\mathrm{FEF}_{25-75}, \mathrm{FEF}_{50}\right.$, $\mathrm{FEF}_{75}$ ) illustrate that there were no statistically signifi-

Table 3. Characterization of the lung function parameters of the 48 sawmill workers according to employment time. The values are preshift readings. [FVC $=$ forced vital capacity, $\mathrm{FEV}_{1.0}=$ forced expiratory volume in $1 \mathrm{~S}$, FEV\% $=\left(100 \times \mathrm{FEV}_{1.0}\right) / \mathrm{FVC}, \mathrm{FEF} \mathrm{F}_{25-75}=$ forced expiratory flow rate during $25-75 \%$ of the $F V C, \mathrm{FEF}_{50}$ and $\mathrm{FEF}_{75}=$ forced expiratory flow rate at 50 and $75 \%$, respectively, of the FVC, $\mathrm{DL}_{\mathrm{CO}}=$ lung diffusion capacity of carbon monoxide]

\begin{tabular}{|c|c|c|c|c|c|c|c|c|c|c|c|c|c|c|}
\hline \multirow{3}{*}{$\begin{array}{l}\text { Employment } \\
\text { time }\end{array}$} & \multicolumn{14}{|c|}{ Lung function parameter } \\
\hline & \multicolumn{2}{|c|}{ FVC } & \multicolumn{2}{|c|}{$\mathrm{FEF}_{1.0}$} & \multicolumn{2}{|c|}{$\mathrm{FEF} \%$} & \multicolumn{2}{|c|}{$\mathrm{FEF}_{25-75}$} & \multicolumn{2}{|c|}{$\mathrm{FEF}_{50}$} & \multicolumn{2}{|c|}{$\mathrm{FEF}_{75}$} & \multicolumn{2}{|c|}{$\mathrm{D} \mathrm{L}_{\mathrm{CO}}^{\mathrm{a}}$} \\
\hline & \multicolumn{2}{|c|}{$\begin{array}{l}\text { Percentage SD } \\
\text { of } \\
\text { predicted } \\
\text { value }\end{array}$} & \multicolumn{2}{|c|}{$\begin{array}{l}\text { Percentage SD } \\
\text { of } \\
\text { predicted } \\
\text { value }\end{array}$} & \multicolumn{2}{|c|}{$\begin{array}{l}\text { Percentage SD } \\
\text { of } \\
\text { predicted } \\
\text { value }\end{array}$} & \multicolumn{2}{|c|}{$\begin{array}{l}\text { Percentage SD } \\
\text { of } \\
\text { predicted } \\
\text { value }\end{array}$} & \multicolumn{2}{|c|}{$\begin{array}{l}\text { Percentage SD } \\
\text { of } \\
\text { predicted } \\
\text { value }\end{array}$} & \multicolumn{2}{|c|}{$\begin{array}{l}\text { Percentage SD } \\
\text { of } \\
\text { predicted } \\
\text { value }\end{array}$} & \multicolumn{2}{|c|}{$\begin{array}{l}\text { Percentage SD } \\
\text { of } \\
\text { predicted } \\
\text { value }\end{array}$} \\
\hline $\begin{array}{l}<5 \text { years } \\
(N=15)\end{array}$ & 96.6 & 8.2 & 94.7 & 7.9 & 98.5 & 7.0 & 96.0 & 19.5 & 98.4 & 21.4 & 98.0 & 26.3 & 87.9 & 24.2 \\
\hline $\begin{array}{l}5-15 \text { years } \\
(N=18)\end{array}$ & 94.5 & 12.8 & 95.0 & 13.9 & 100.7 & 5.5 & 99.4 & 28.6 & 101.6 & 32.4 & 106.5 & 38.6 & 88.8 & 14.7 \\
\hline $\begin{array}{l}>15 \text { years } \\
(N=15)\end{array}$ & 97.9 & 13.0 & 96.0 & 14.2 & 98.8 & 8.2 & 96.4 & 29.0 & 102.5 & 33.0 & 96.9 & 34.2 & 100.0 & 28.7 \\
\hline All $(N=48)$ & 96.2 & 11.5 & 95.2 & 12.2 & 99.4 & 6.8 & 97.4 & 25.7 & 100.9 & 29.0 & 100.8 & 33.4 & 91.9 & 22.9 \\
\hline
\end{tabular}

a Numbers for $D_{60}$ : $<5$ years of employment, $N=14 ; 5-15$ years of employment, $N=16$; $>15$ years of employment, $N=13$; all employment groups combined, $N=43$. 
Figure 2. Mean differences, with the $95 \%$ confidence intervals $(95 \% \mathrm{CI})$, in carbon monoxide diffusion capacity $\left(\mathrm{DL}_{\mathrm{co}}\right.$ ) (after work compared with before work) among the exposed sawmill workers. The workers have been grouped according to a daily average exposure of $\leq 50 \mathrm{mg} \cdot \mathrm{m}^{-3}(\mathrm{~N}=12)$ and $>50 \mathrm{mg} \cdot \mathrm{m}^{-3}(\mathrm{~N}=26)$ for total terpenes. The mean differences in the $\mathrm{DL}_{\mathrm{co}}$ values for the whole study population are also shown.

Figure 3. Mean differences, with the $95 \%$ confidence intervals $(95 \% \mathrm{Cl})$, in the air volume, expressed in liters, between the postshift and preshift values of forced volume capacity (FVC) and the forced expiratory volume in $1 \mathrm{~s}$ (FEV ${ }_{1.0}$ ) among the sawmill workers. The workers have been grouped according to a daily average exposure of $\leq 50 \mathrm{mg} \cdot \mathrm{m}^{-3}(\mathrm{~N}=18)$ and $>50 \mathrm{mg} \cdot \mathrm{m}^{-3}(\mathrm{~N}=28)$ for total terpenes. The mean differences in the FVC and $\mathrm{FEV}_{1.0}$ values for the whole study population $(\mathrm{N}=46)$ are also shown.
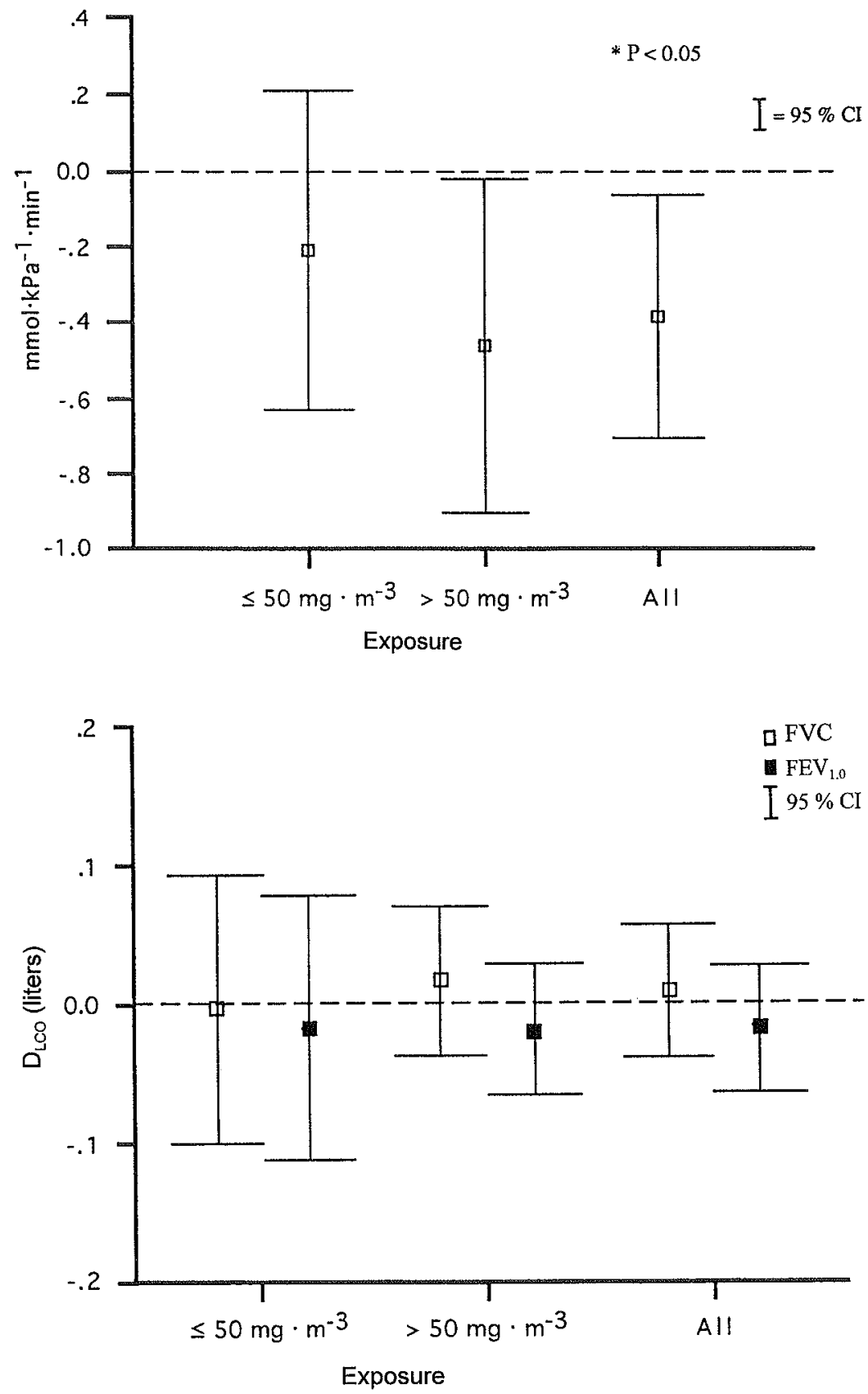

cant changes in the lung function variables over the workshift between the low and the medium-high terpene exposure groups $(\mathrm{P}>0.05$, Mann-Whitney rank sum test). No correlation ( $\mathrm{P}>0.05$ Spearman correlation) was found between the exposure to different concentrations of total terpenes and the change in lung function variables over a workshift.

\section{Methacholine test}

After known asthmatics and atopics were excluded, 54\% $(\mathrm{N}=16)$ of the examined sawmill workers had a $\mathrm{PD}_{20}$ of less than $8 \mathrm{mg}$, and eight of these workers were in the group with the shortest employment time. The change in
$\mathrm{FEV}_{1.0}$ per milligram of cumulated inhaled dose of methacholine (the slope) was highest within this group of workers as well, giving a statistically significant difference $(P<0.05$, Mann-Whitney rank sum test) in methacholine reactivity for these laborers when compared with workers with an employment time exceeding five years (figure 5).

\section{Discussion}

There was a relatively wide range in the personal exposure to terpenes among the laborers in each sawmill 


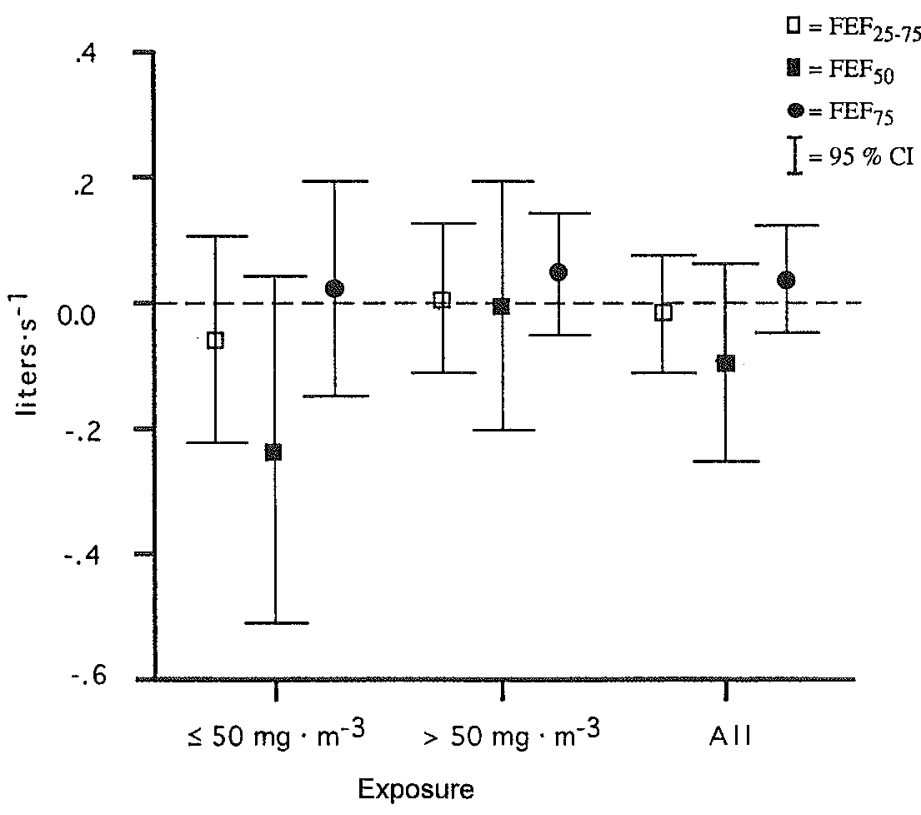

Figure 4. Forced expiratory flows during $25-75 \%$ of the forced volume capacity (FVC) $\left(\mathrm{FEF}_{25-75}\right)$ and at $50 \%\left(\mathrm{FEF}_{50}\right)$ and $75 \%\left(\mathrm{FEF}_{75}\right)$ of the $\mathrm{FVC}$, expressed as the mean differences (with $95 \%$ confidence intervals), in liters per second, after work compared with those before work. The workers have been grouped according to a daily average exposure of $\leq 50 \mathrm{mg} \mathrm{m}^{-3}(\mathrm{~N}=12)$ and $>50 \mathrm{mg} \mathrm{m}^{-3}$ $(N=26)$ for total terpenes. The mean differences for the whole study population are also shown $(N=46)$.

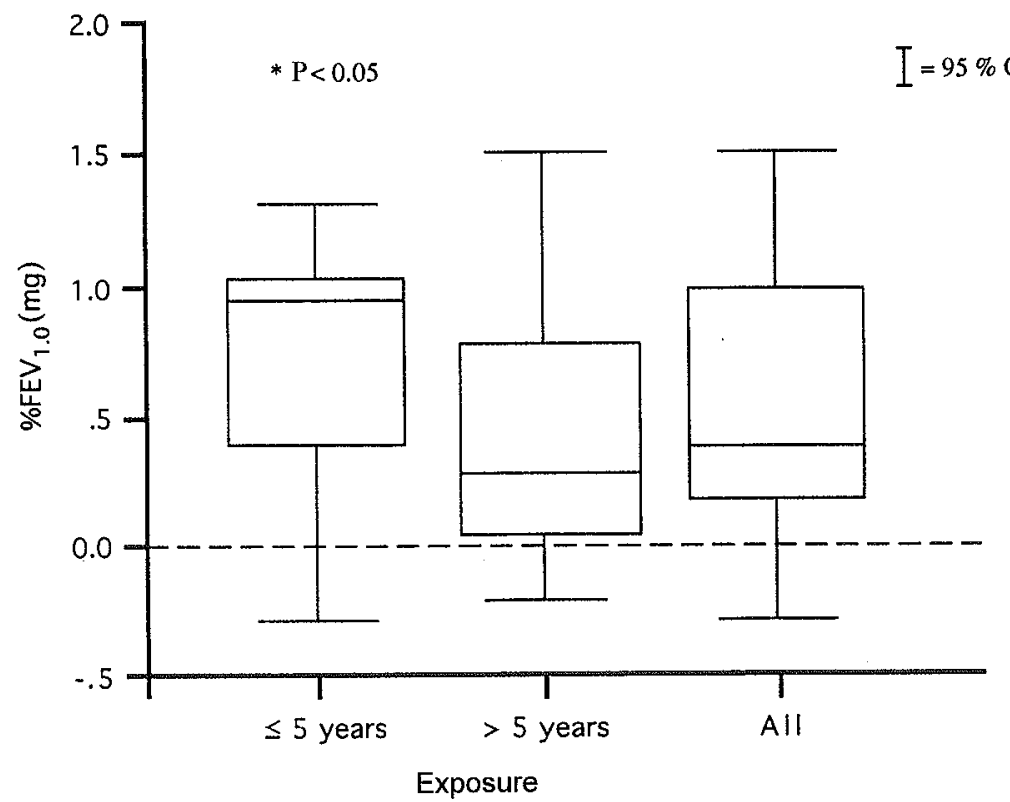

Figure 5. Box plots, with the $95 \%$ confidence intervals $(95 \% \mathrm{Cl})$ showing the slope values (first quartile, median and third quartile, in $\log _{10}$ values) in the percentage of change in forced expiratory volume in $1 \mathrm{~s}\left(\mathrm{FEV}_{1.0}\right)$ per milligram of the cumulated inhaled dose of metacholine. The workers have been grouped according to an employment time of $\leq 5$ years $(N=13)$ and $>5$ years $(N=20)$. The slope value for the whole study population $(N=33)$ is also shown. (table 1). The difference in the personal exposure levels during a workshift was dependent on which task the worker was performing during the day of examination. Usually sawing trees, edging boards, and sweeping sawdust away from the floor and the machinery resulted in the highest exposures of total terpenes $(\mathrm{GM}=77 \mathrm{mg}$. $\mathrm{m}^{-3}$ ). Workers sorting boards were exposed to the lowest levels of terpenes during the workshift $(\mathrm{GM}=37 \mathrm{mg}$. $\mathrm{m}^{-3}$ ). The sorting was performed within the saw shed but relatively far away from the saws emitting sawing fumes. Therefore, these workers had the lowest exposure to terpenes, compared with the other members of the work force. However, in each sawmill studied, some workers were exposed to air levels close to, or exceeding, the present Swedish exposure limit for monoterpenes, and it is therefore necessary to perform exposure assessments in sawmills.

There was a good correlation (correlation coefficient $=0.84$ ) between the concentration of verbenols in the postshift urine samples and the personal exposure to $\alpha$-pinene during the workshift (figure 1). In general, the workers who were exposed to the highest level of $\alpha$ pinene during a workday also had the highest concentration of verbenols in their urine at the end of the workshift. 
In experimental studies on humans, Åstrand (22) has shown that the uptake and distribution of vapors from different organic solvents increases when the work load (ie, the ventilation rate) increases. A heavy work load thus leads to higher exposure than light work does.

Biological monitoring takes into account all the physicochemical and biological variables that influence the uptake or the absorption of a substance, such as the ventilatory parameters and individual variability in absorption and metabolism. Thus we suggest that the determination of verbenols in urine samples can be a complementary technique to conventional air sampling, when personal exposure to sawing fumes is being assessed in sawmills. However, due to the short elimination halftime of $0.6 \mathrm{~h}$ for verbenols, it is necessary that the urine samples be collected directly after the end of the workshift in a standardized way.

The determination of urinary metabolites can be used as a tool to study the effect of changes in work practices.

The reduction of personal exposure to styrene using respiratory protective equipment compared with not using such a device has been studied in a factory producing plastic boats (24). Styrene exposure in the breathing zone was reduced by $56-92 \%$ when a respirator was worn, and it was also shown that the levels of styrene metabolites in the workers' urine was reduced by $30-99 \%$ after the respirator was worn.

In sawmills, the determination of verbenols in urine can be used to evaluate whether measures taken to reduce personal exposure to sawing fumes have been effective or not. If the level of $\alpha$-pinene in the workplace atmosphere is reduced, a decrease in the concentration of verbenols would probably also occur in the workers' urine as the amount of $\alpha$-pinene inhaled is decreased. However, the usefulness of determining verbenols in workers' urine to study the effectiveness of technical improvements to reduce personal exposure to sawing fumes should be evaluated in future studies.

The static sampling of microorganisms and the personal sampling of wood dust showed relatively low exposure to these substances in the sawmills. No correlation between exposure to these substances and acute effects on lung function parameters could be found.

This study was designed to examine the exposure situation in Swedish sawmills and to correlate the exposure to acute symptoms and acute lung function effects. The results show an increase in eye irritation over the workshift, but no statistically significant increase in any other acute symptoms. In accordance with earlier studies (3), no changes in dynamic spirometry were found over the workshift.

However, a small, but statistically significant decrease in diffusing capacity was seen over the workshift. This finding is an agreement with those of another study performed recently in Swedish sawmills (unpublished observations). The reason for this reduction in diffusing capacity among the sawmill workers is not known. One possible explanation is that there was some degree of alveolar inflammation. However, neither $\alpha$-pinene, $\beta$-pinene, nor $\Delta^{3}$-carene have been shown to cause inflammation in the alveolar region of the human lung (25). The decrease in diffusing capacity cannot currently be fully explained, but we suggest that exposure to other substances of wood origin in sawmills may cause this impairment. Future studies must be performed to evaluate this assumption.

Neither subjective symptoms nor lung function changes seemed to correlate with the terpene concentrations in the workplace atmosphere, despite the fact that the total terpene concentration ranged from 11 to 158 $\mathrm{mg} \cdot \mathrm{m}^{-3}$. These findings are also in agreement with those of earlier experimental studies (24) in which healthy subjects showed no lung function impairment when exposed to terpenes $\left(450 \mathrm{mg} \cdot \mathrm{m}^{-3}\right)$.

Increased reactivity to methacholine is known to occur in allergic inflammatory conditions such as asthma. Nonallergic inflammation caused by exposure to swine dust has been shown to induce bronchial hyperresponsiveness (26). Our findings imply that workers in sawmills can develop an increased hyperresponsiveness, possibly caused by exposure to substances released during the sawing of pine or spruce. To identify the cause of this hyperresponsiveness is a future task.

This study illustrates well the problems of assessing health effects with a cross-sectional study design. When the time of employment is considered, the workers with short employment time ( $\leq 5$ years) had an increased methacholine reactivity compared with those with an employment time of more than five years. This finding indicates a "healthy worker effect" in the cross-sectional material (ie, the workers who have developed disorders in the respiratory tract may have left their jobs). Thus it is not possible to assess long-term effects on the respiratory tract due to exposure to sawing fumes in sawmills from this study.

\section{Acknowledgments}

This work was supported by grants from the Swedish Work Environment Fund (grant no 89-1370), the Department of Occupational and Environmental Medicine, University Hospital of Northern Sweden, Umeå, and the National Institute of Working Life, Umeå.

The skillful technical assistance of Ms Karin Lindström-Espeling, Ms Anna Wenngren, Ms Annika Hagenbjörk-Gustafsson, and Ms Gete Hestvik is greatfully acknowledged. 


\section{References}

1. Statistiska centralbyrån. Statistical yearbook of Sweden '92. Örebro (Sweden): Statistiska centralbyrån, 1991.

2. Eriksson K, Levin J-O. Identification of cis-and trans-verbenol in human urine after occupational exposure to terpenes. Int Arch Occup Environ Health 1990;62:379-383.

3. Hedenstierna G, Alexandersson R, Wimander K, Rosén G. Exposure to terpenes: effects on pulmonary function. Int Arch Occup Environ Health 1983;51:191-8.

4. Eriksson K, Levin J-O, Rhén M, Lindahl R. Evaluation of a diffusive sampler for air sampling of monoterpenes. Analyst 1994;119:85-8.

5. Eriksson K, Levin J-O. Field validation of a diffusive sampler for the assessment of personal exposure to sawing fumes. Chemosphere 1995;30:1541-9.

6. Levin J-O, Eriksson K, Falk A, Löf A. Renal elimination of verbenols in man following experimental $\alpha$-pinene inhalation exposure. Int Arch Occup Environ Health 1992;63:571-3.

7. Goldsmith DF, Shy CM. Respiratory health effects from occupational exposure to wood dusts. Scand J Work Environ Health 1988:14:1-15.

8. Malo J-L, Cartier A, Boulet L-P. Occupational asthma in sawmills of eastern Canada and United States. J Allergy Clin Immunol 1986;78:392-8.

9. Enarson D, Chan-Yeung M. Characterization of health effects of wood dust exposures. Am J Ind Med 1990;17:33—8.

10. Dahlqvist $M$, Alexandersson R, Ulfvarson U. Pulmonary function changes in sawmill workers - a prospective study of occupational exposure to sawfumes. Occup Hyg 1994;1:1726.

11. Grimm W, Gries H. Turpentine. In: Parmeggiani L, editor. Encyclopaedia of occupational safety and health. Geneva: Industrial Labour Organisation 1983:2229.

12. Hellerström S. Hypersensitivity tests in professional eczema and their applicability and sources of error. Acta Derm Venerol (Stockh) 1939;20:657.

13. Pirilä V, Siltanen E. On the chemical nature of the eczematogenic agent in oil of turpentine III. Dermatologica $1958 ; 117: 1-8$

14. Halpin D, Graneek B, Lacey J, Nieuwenhuijsen M, Williamson $\mathrm{P}$, Venables $\mathrm{K}$, et al. Respiratory symptoms, immunological responses, and aeroallergen concentrations at a sawmill. Occup Environ Med 1994;51:165 -72.

15. Falk AA, Hagberg MT, Löf AE, Wigaeus-Hjelm EM, Zhiping
W. Uptake, distribution and elimination of $\alpha$-pinene in man after exposure by inhalation. Scand J Work Environ Health 1990;16:372-8.

16. Palmgren U, Ström G, Blomquist G, Malmberg P. Collection of airborne micro-organisms on Nucleopore filters, estimation and analysis-CAMNEA method. J Appl Bacteriol 1986;61: $401-6$.

17. Borg G. Psychophysical bases of perceived exertion. Med Sci Sports Exerc 1982;14:377-81.

18. American Troracic Society. ATS statement - Snowbird Workshop on Standardization of Spirometry [editorial]. Am Rev Respir Dis 1979;119:831-8.

19. Ogilvie C, Forster R, Blakemore W, Morton J. Standardized breathholding technique for the clinical measurement of the diffusing capacity of the lung for carbon monoxide. J Clin Invest 1957;36:1-17.

20. Quanjer PH, Tammeling G. Clinical respiratory physiology. chapter 1; summary of recommendations. Bull Eur Physiopathol Exp 1983;19 suppl 5:7-10.

21. Malmberg P, Larsson K, Thunberg S. Increased lung deposition and biological effect of methacholine by use of a drying device for bronchial provocation tests. Eur Respir J 1991;4: 890-8.

22. Astrand I. Effects of physical exercise on uptake, distribution and elimination of vapors in man. In: Fiserova-Bergerova V, editor. Modelling of inhalation exposure to vapors: uptake, distribution, and elimination; vol II. Boca Raton (FL): CRC Press, 1983:107-30.

23. Löf A, Brohede C, Gullstrand E, Lindström K, Solenberg J, Wrangskog $\mathrm{K}$, et al. The effectiveness of respirators measured during styrene exposure in a plastic boat factory. Int Arch Occup Environ Health 1993;65:29-34.

24. Domanski J Jr. Toxicology. In: Zinkel D, Russell J, editors. Naval stores: production, chemistry, utilization. New York (NY): Pulp Chemical Association, 1989.

25. Larsson $\mathrm{K}$. Terpenexponering påverkar cellsammansättningen i luftvägarna utan att påverka lungfunktionen [Terpene exposure influences the composition of cells in the airways without affecting lung function]. Stockholm: Arbetarskyddsverhet, 1992:139 - 46. Arbete och Hälsa 21. English summary.

26. Malmberg P, Larsson K. Acute exposure to swine dust causes bronchial hyperresponsiveness. Eur Respir J 1993;6:400-4.

Received for publication: 6 April 1995 